\title{
Sugar prices development: The relation among selected commodity stocks exchange
}

\author{
Luboš Smutka \\ Faculty of Economics and Management, \\ Czech University of Life Sciences in Prague, \\ Crech Republic \\ smutka@pef.czu.cz. \\ Patrik Rovný \\ Faculty of Economy and Management, \\ Slovak University of Agriculture in Nitra, \\ Slovak Republic \\ patrik.rovny@uniag.sk

\section{Jozef Palkovič} \\ Faculty of Economy and Management, \\ Slovak University of Agriculture in Nitra, \\ Slovak Republic \\ jozef.palkovi@@uniag.sk
}

Abstract. World sugar market has been oscillating between surplus and deficit states. After the long-term period of surpluses, we recorded several deficits during the last ten years development and the state of global sugar stocks decreased to about $85 \mathrm{mln}$. tonnes in 2019/2020. The volume of consumption (176 mln. tonnes) passed over the volume of production $(167 \mathrm{mln}$. tonnes). The last years sugar market development put world sugar prices under bearish pressure. Brazil and Australia are the only ones with a rather liberal, unprotected sugar market, while in all other countries at least the domestic market is affected by regulations. The processed paper is interested to analyse the world sugar price development at the level of several markets/stock exchanges. The objective is to identify whether there are existing or not some common features and relations influencing global and regional sugar price development. Causality and direction of causal relationship (causality in statistical meaning, better said precedency) was investigated by using Granger causality test. Evidence of long run equilibrium and number of cointegration vectors between markets was investigated by Johansen test. In final, was estimated relationship between markets by vector error correction mechanism. Reaction of prices in key markets to external impulse was expressed using impulse-response function. Based on above mentioned analyses,

Received: October, 2019 1st Revision: March, 2020 Accepted: May, 2020 
the strong relations were confirmed among ISA, New York 11 and London No. 5. Granger Causality test confirmed strong position of London No.5 and New York 11, which influence other markets. There was confirmed also causality in direction from New Delhi to Sao Paulo and from Sao Paulo to Mexico. Results of the VECM confirmed Granger causality and strong position of New York 11 and emphasized also role of ISA: In comparison of results obtained by correlation, causality and error correction mechanism, was confirmed important role of New York 11 in all these analyses.

Keywords: sugar prices, commodity, stock exchange, relations, London, New York, ISA, differences.

JEL Classification: F14, F10, F63, Q02, Q17

\section{INTRODUCTION}

World sugar market has been fast developing. Its territorial structure is changing and also its dynamics is fast developing and extremely volatile. Sugar has being widely traded for its precious value since many centuries ago. Sugarcane offers production substitutes to food, such as feed, fibre and energy such as biofuels (sugar-based ethanol) and/or co-generation of electricity. Sugar is, after oil, the second most-traded commodity in the world. (Grethe, Nolte \& Banse, 2008). By Surca (2017) World sugar production exceeds 115 million tonnes and is located in growing areas of raw materials: beet and cane sugar. Svatoš, Maitah and Belova (2013) state, that he growth of the world sugar production relies on the increase in the sugar crops cultivation. In the years 2008/2009 - 2011/2012 alone the worldwide sugar beet production reached nearly 272 million tons, with an average growth rate of production standing at about $2.5 \%$ per year. In the case of sugar cane, during the same period its production reached the level of about 1794 million tons and the rate of the production growth achieved an average of $2.7 \%$ per year. The main volume of sugar crops production is made up primarily of sugar cane. While sugar beet is grown in about 50 countries, the sugar cane is cultivated in about one hundred countries. (Babuněk, 2016) Twenty percent of the world's supply of sugar is derived from sugar beet, mainly cultivated in industrialized countries, while the remaining $80 \%$ of the world's sugar supply is derived from sugar cane, mainly cultivated in tropical climates in developing countries (Řezbová et al., 2013). Currently, there are about 110 countries produce sugar from either cane or beet, and eight countries produce sugar from both cane and beet. Sugarcane, on average, accounts for nearly $80 \%$ of global sugar production. In 2019 the top ten producing countries (India, Brazil, Thailand, China, the US, Mexico, Russia, Pakistan, France, Australia) accounted for nearly $70 \%$ of global output. Brazil is the World's largest sugar producer and largest sugar exporter. (Haley, 2013). Brazil uses a substantial amount of sugar cane for ethanol production. (Koo \& Taylor, 2012) Sugar is produced from sugarcane in Brazil. In the mid-1990s, the country became the greatest producer and exporter of this commodity. Since 2009 Brazil has been responsible for more than 20 percent of the world production of sugar and for $60 \%$ of the total export volume. About $70 \%$ of the Brazilian production is directed to the external market (Jacomini, Burnquist, 2018). The corn ethanol produced in the US and sugarcane ethanol produced in Brazil, are the world's leading sources of biofuel. (Crago, Khanna, Barton, Giuliani \& Amaral, 2010) The EU had been both the second largest importer and second largest exporter in the world market (Moyo \& Spreen, 2011). According to the independent experts such as LMC International, many of the EU beet industries are now ranked in the top quartile of world industries for cost competitiveness (Severová et al., 2011). The sugar market is one of the most regulated ones (Kovářová et al., 2017; Récky, 2014). 


\section{LITERATURE REVIEW}

Between years 2001 and 2020, World sugar production increased from cc $120 \mathrm{mln}$. tonnes to about $170 \mathrm{mln}$ tonnes, the equivalent to an average annual growth of $2.01 \%$ (figure 1). However, the second half of the current decade has seen a considerable deceleration in world sugar production. Major sugar producing and also consuming markets include India, the EU, China, Brazil, the US, Indonesia, Russia, Pakistan, Mexico and Egypt. Table 1 shows the top five producer and consumer countries in the World (F.O.Licht, 2020).

Table 1

Top five largest World producers and consumers (in mln. tonnes)

\begin{tabular}{|c|c|c|c|c|c|}
\hline \multicolumn{3}{|c|}{ Largest producers } & \multicolumn{3}{c|}{ Largest consumers } \\
\hline 1 & India & 33.30 & 1 & India & 25.39 \\
\hline 2 & Brazil & 29.29 & 2 & EU-28 & 17.94 \\
\hline 3 & EU-28 & 18.18 & 3 & China & 16.10 \\
\hline 4 & Thailand & 15.44 & 4 & Brazil & 10.47 \\
\hline 5 & China & 10.71 & 5 & USA & 10.19 \\
\hline
\end{tabular}

Source: F.O.Licht, 2020 (https://www.agra-net.com/agra/international-sugar-and-sweetener-report/)

Sugar trade with the United States is complicated due to the political strength of domestic producers and the resulting policies used to support the domestic price. A majority of trading partners are located in the western hemisphere and are efficient sugar producers that are in close proximity to the U.S. market (F.O.Licht, 2020). Other factors, however, have changed the sugar market trade. This includes external policies, of which the tariff rate quota (TRQ) is chief. (Garside et al., 2004) Distortions in this market occur if an efficient and large producing country is not included among the countries that are allowed to export sugar through TRQs and must then incur a prohibitive over-quota tariff to access the U.S. market (Fuller \& Kennedy, 2019).

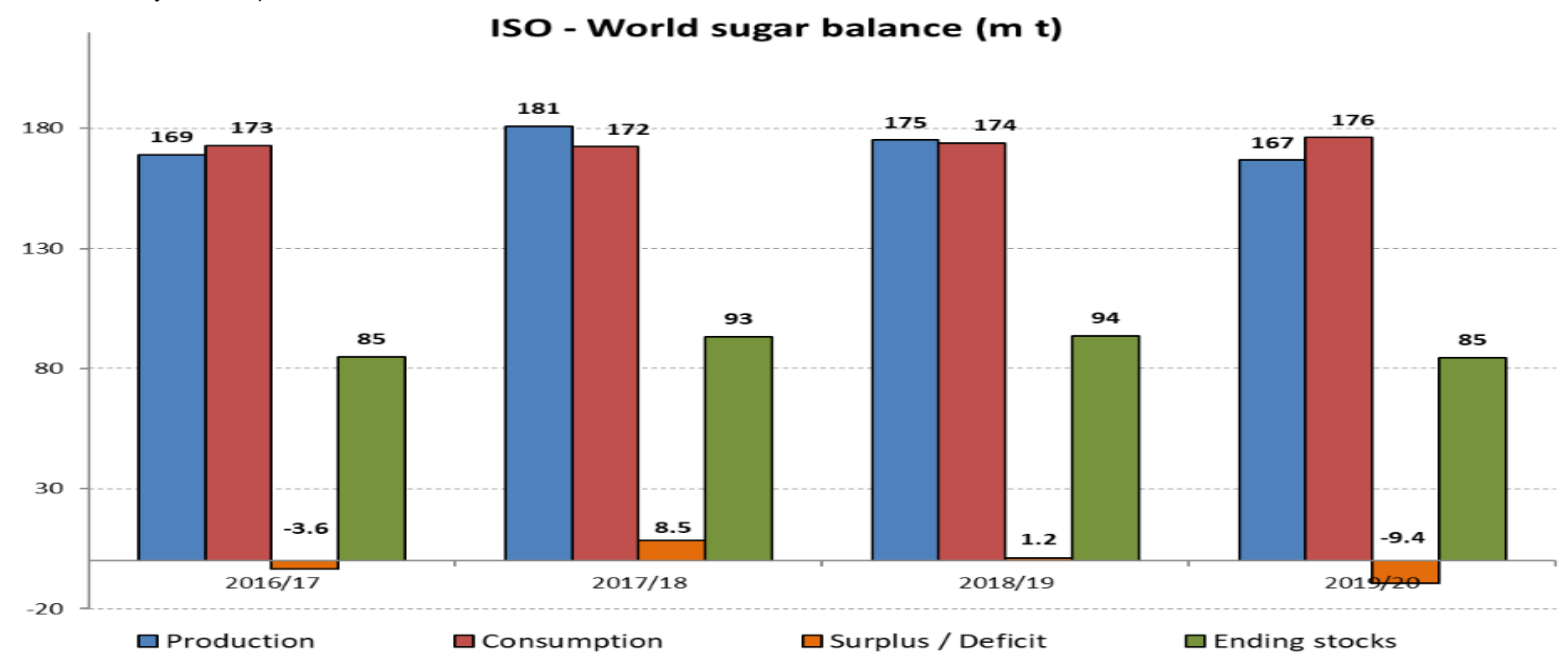

Figure1. World sugar balance in mln. tonnes

Source: F.O.Licht, 2020 (https://www.agra-net.com/agra/international-sugar-and-sweetener-report/)

The most important drivers which influence sugar supply and demand include: population growth, per capita incomes, the price of sugar and alternative sweeteners and health concern debate (Krejčí et al., 2016; Nagyová et al., 2011; Bilyk et al., 2020). It is also necessary to mention an important fact related to the state 
of the global sugar market and it is its extreme concentration - especially trade concentration as top five exporters (Brazil, Thailand, EU, Australia, India) are responsible on average for nearly $70 \%$ of the world trade in 2016-2020 (F.O.Licht, 2020). Brazil, as the largest producing and exporting country in the world, dominates world trade, accounting for about $45 \%$ of global exports. On the other hand, Indonesia, China the United States are considered to be world's largest importers. World sugar market has been oscillating between surplus and deficit states. After the long-term period of surpluses, we recorded several deficits during the last ten years development and the state of global sugar stocks decreased to about $85 \mathrm{mln}$. tonnes in 2019/2020 (figure 1). The volume of consumption (176 mln. tonnes) passed over the volume of production (167 mln. tonnes) (F.O.Licht, 2020). The last years sugar market development put world sugar prices under bearish pressure. For example the ISA Daily Price in January 2020 started the year above 14.00 cents/lb, fell below 11.00 cents/lb in May 2020. The ISO White Sugar Price Index decreased from USD432.04/tonne in 2017 to USD333.40/tonne in 2020 (May). Brazil and Australia are the only ones with a rather liberal, unprotected sugar market, while in all other countries at least the domestic market is affected by regulations (F.O.Licht, 2020). A comparison of the production costs shows, that over time, only Brazil, Australia, Thailand and partly South Africa would be able to produce at world market prices. (Zimmermann \& Zeddies, 2002; Rezbova et al., 2015; Hndi et al., 2016) As global sugar market is rather specific especially because of different sugar policies applied by individual countries all around the world and also because of significant protectionism of selected countries sugar market. (Haley \& Polet, 2011). There are existing the significant differences in sugar price at the level of individual countries and could be demonstrated in the figure 2 .

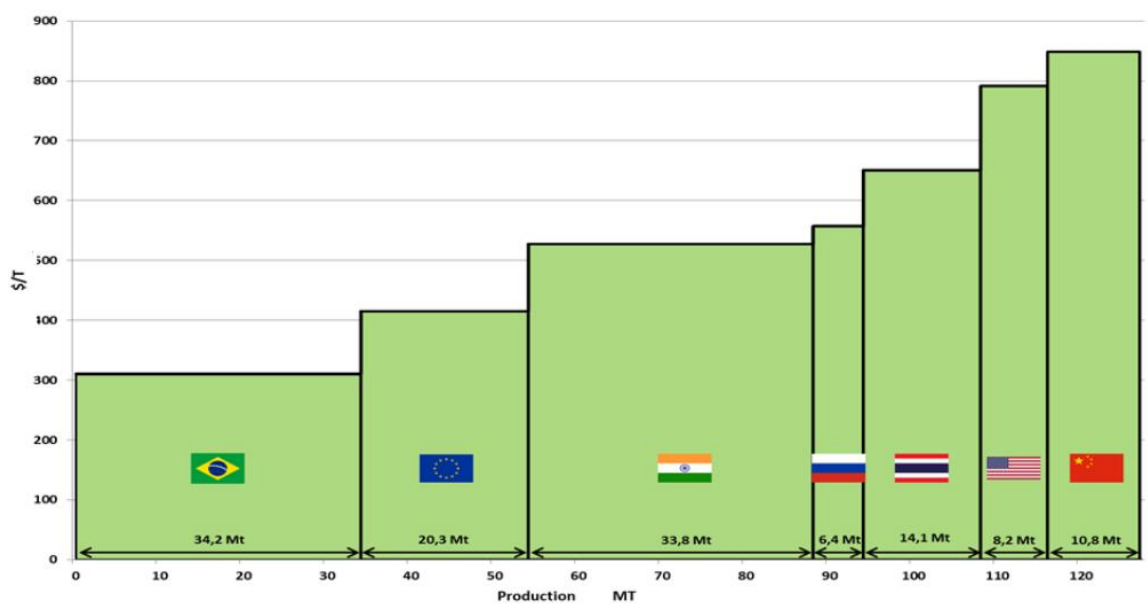

Figure 2. Prices of refined sugar and quantities produced by the main world producers in 2018 Source: Agriculture Sratégies, 2020 (http://www.agriculture-strategies.eu/en/2019/07/the-european-sugarpolicy-a-policy-to-rebuild/)

The global sugar market passed through the significant process of transformation as the volume and price of global sugar market changed during the last several decades. 


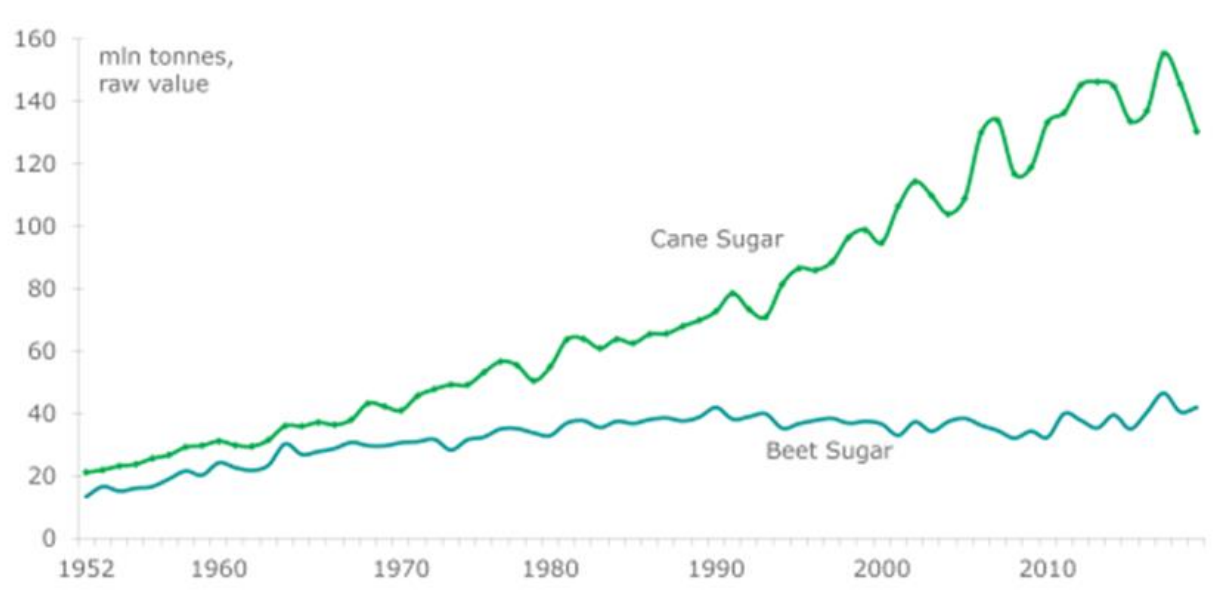

Figure 3. World Beet and Cane Sugar Production 1952/53 - 2019/20

Source: F.O.Licht, 2020 (https://www.agra-net.com/agra/international-sugar-and-sweetener-report/)

While the global sugar production simply increased its volume, the global sugar price development passed the extremely volatile prices of development as could be demonstrated through the figures $3,4,5$ and 6 .

As noted by Pop et al. (2013), sugar has been one of the most volatile agricultural commodities, posing a challenge for policymakers in dealing with price instability. In addition, regarding local markets, sugar prices may differ significantly from country to country. (Elobeid \& Beghin, 2006) World sugar prices soared to a 29-year high of nearly 30 cents a pound in early 2010 before falling back to half that level by early summer. Still, they remain 50 percent higher than average over the past 20 years. Was this price spike a temporary oscillation caused by a supply shock or does it reflect a more permanent fundamental shift in global market dynamics? Evaluation of economic and policy factors driving production and trade in key global sugar markets supports both perspectives: underlying dynamics related to Brazil's exchange rates and ethanol's role in energy markets are putting upward pressure on global prices. However, the volatility of price movements in the past year was mostly the result of supply shortfalls tied to changing economic incentives, weather disruptions, and policy factors in other countries. (Drabik et al., 2014; Cermak et al., 2017) The U.S. remains largely insulated from global sugar price movements, but external fluctuations are felt in the United States, particularly when prices are high (McConnell et al., 2010). Frate and Brannstrom (2015) show that there is conflict between the agrarian reform policies of big countries and ethanol policies and highlights the importance of sugarcane to family agriculture. 


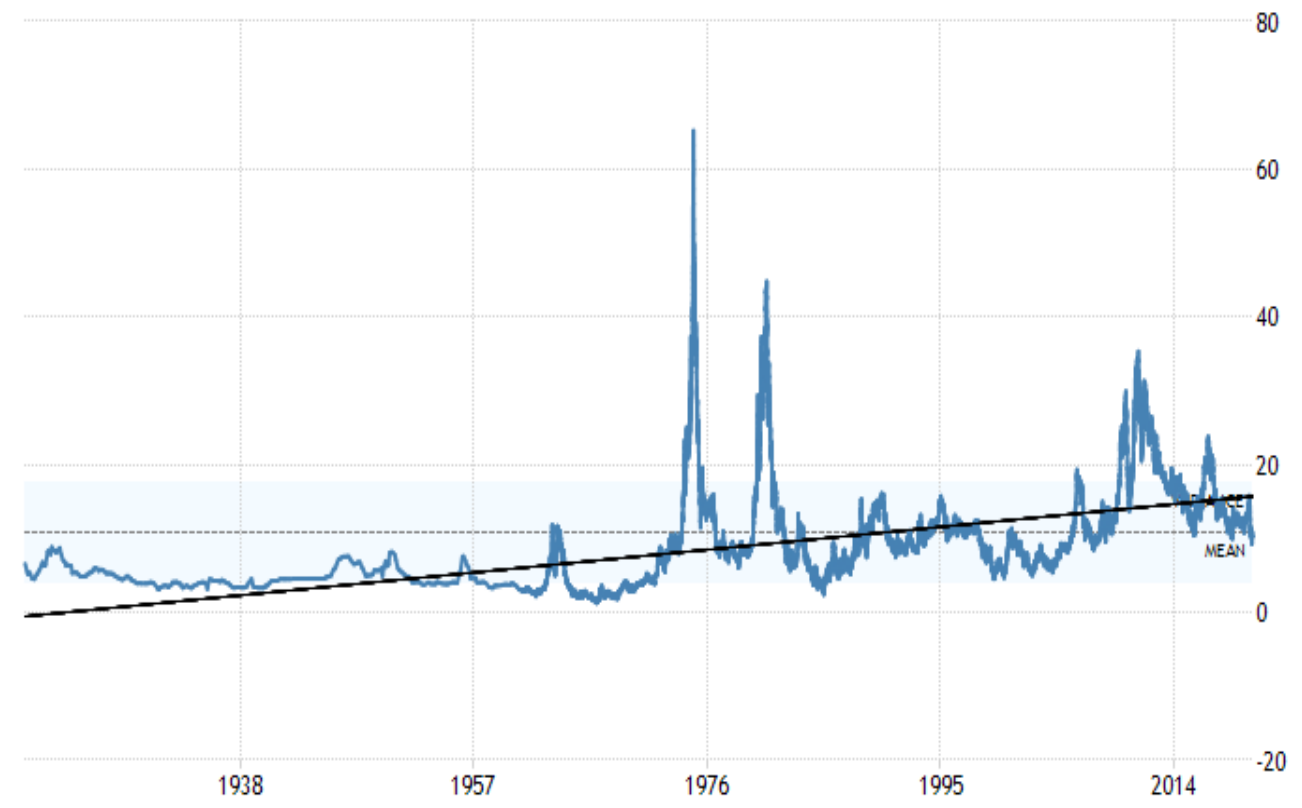

Figure 4. Development of sugar price indexes

Source: Trading Economics, 2020 (https://tradingeconomics.com/commodity/sugar)

Serra, Zilberman \& Gil (2010) studied a strong link in price level and volatility of food and energy markets. Lima et al. (2019) analyzed the relation between sugar and ethanol using the econophysics methods to analyze long term cross-correlations between these two commodities. The good example of sugar price volatility is the Sugar No. 11. As Sugar No. 11 contract is the world benchmark contract for raw sugar trading and is available on The Intercontinental Exchange (ICE). The size of each contract is 112,000 pounds. U.S and Brazilian exchange rates also have shown to influence world prices. (Kramer, 2016) The sugar prices displayed in Trading Economics are based on over-the-counter (OTC) and contract for difference (CFD) financial instruments (Pereda et al., 2019). Because of the extreme pressure existing at the world sugar market during the last ten years period - the significant sugar price reduction was recorded in period 2010 -2020. Since it is product also traded in the international market, it is expected that its market will be influenced by the price of refined sugar traded on the London Stock Exchange (figure 6), as well as by the values of sugar marketed in the international market of New York and its respective premium of polarization. Thus, it is believed that the sugar price formed in the foreign market - whether raw or white - should influence price formation in the domestic market. In addition, the supermarket sector identified by Rodrigues and Moraes (2007) as being highly concentrated, can exert power with refined sugar producers. The analysis associating price level and market structure allows us to conclude that, despite the State's regulation of the product, the market structure was strongly related to price levels, demonstrating a positive relationship between price level and market concentration.

The sugar market became extremely sensitive for changes in consumption patterns and changes in volume of production and stocks (Dimpfl \& Peter, 2018). The extreme volatility is not related to only NYSE (figure 5), but also LSE recorded the significant price transformation during the last decade (Barassi \& Ghoshray, 2007). 


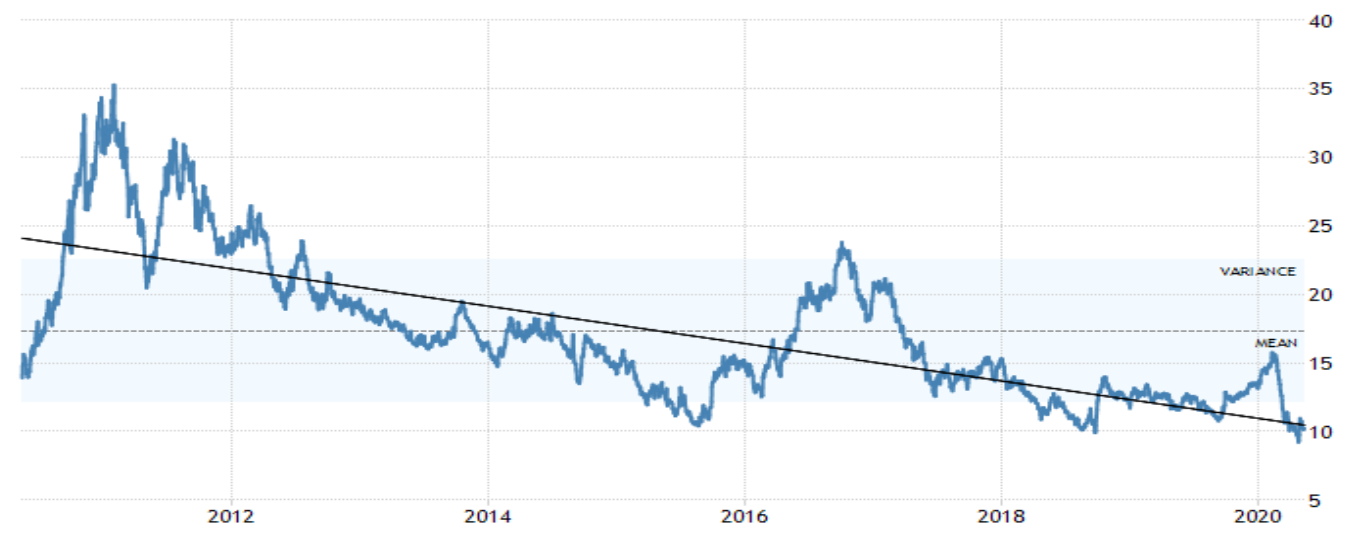

Figure 5. Development of sugar price indexes on NYSE

Source: Trading Economics, 2020 (https://tradingeconomics.com/commodity/sugar)

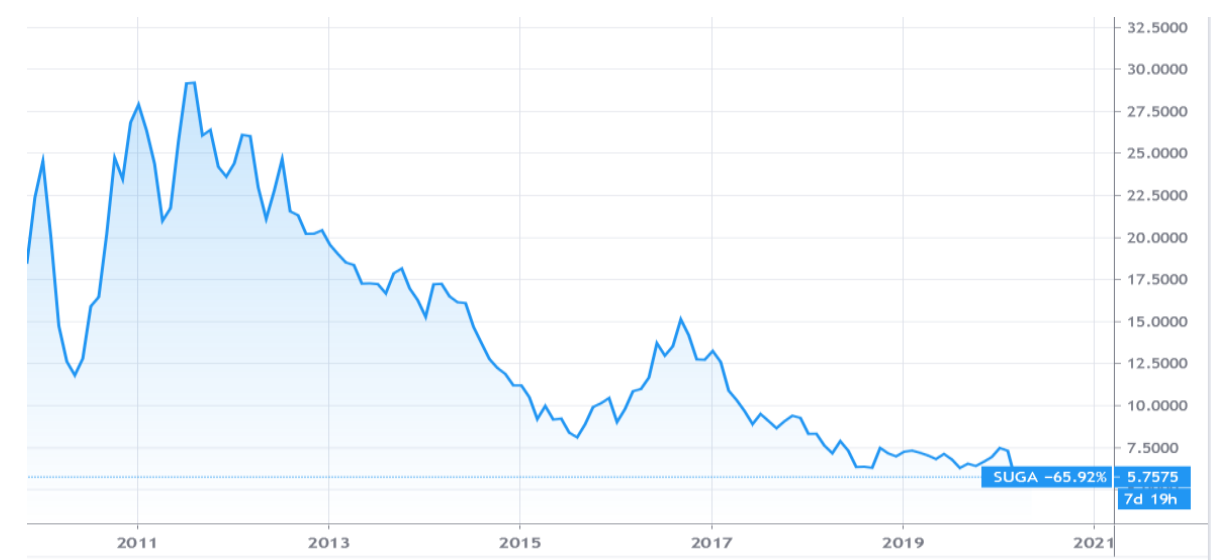

Figure 6. Development of sugar prices on London stock Exchange in USD/1b Source: Tradingview, 2020 (https://uk.tradingview.com/symbols/LSE-SUGA/)

Total world sugar trade is projected to increase by $16.2 \%$, from 45.6 to 53.0 million metric tons over the 2016-2026 period. Most exporting countries will increase their sugar exports for the same period. Exports will increase $13.2 \%$ for Brazil, and $13.8 \%$ for Thailand. Exports are also expected to increase for Cuba (17.1\%) during the same time period. World sugar price, referred to as the ICE No. 11 price of sugar, is projected to decrease from $\$ 0.166 / \mathrm{lb}$ in 2016 to $\$ 0.137$ in 2026. (Taylor,2017)

Based on available findings it is possible to highlight an interesting transformation of world sugar market and especially price transformation as the price is considered to be the indicator of the state of market and it reflects the state of supply/demand relations. The processed paper is interested to analyse the world sugar price development at the level of several markets/stock exchanges. The objective is to identify whether there are existing or not some common features and relations influencing global and regional sugar price development.

\section{METHODOLOGY}

The processed paper is analysing the relation among the key commodity stock exchange focused on trade in sugar. Specifically, to test for the presence and degree of the co-movement over the ten-year period 
from 2010 till 2020. The following global sugar market actors - sugar exchange stocks and International Sugar alliance:

- NYSE/New York Stock: New York No.11,

- LSE/London Stock Exchange: London No.5,

- NCDEX/National Commodity and Derivatives Exchange - Kolhapur-M Grade (India),

- ISA/International Sugar Agreement,

- 3B/Brazil Bolsa Balcao/Brazil-Sao Paulo ESALQ,

- BMV/Bolsa Mexicana de Valores/Mexico,

- Zhengzhou Commodity Exchange/ZCE China,

- MOEX/Moscow Exchange Russia.

As the source of daily trade data (daily price was recalculated in USD based on actual USD exchange rate) we used the F.O.Licht database.

Relationship between sugar prices in the world markets was investigated using following methods. First was investigated correlation coefficients between prices in order to identify markets with similar tendency. Causality and direction of causal relationship (causality in statistical meaning, better said precedency) was investigated by using Granger causality test. Evidence of long run equilibrium and number of cointegration vectors between markets was investigated by Johansen test. In final, was estimated relationship between markets by vector error correction mechanism. Reaction of prices in key markets to external impulse was expressed using impulse-response function. All calculations were performed in Stata.

\section{Correlation analysis}

Significant correlation between prices is main assumption of existence of any relationships between prices. This was conducted using Pearson's correlation coefficient. This can be calculated using following formula, where $x_{i}$ and $y_{i}$ are observation of two related variables. $r_{x, y}$ denotes correlation coefficient measuring strength of relationship between $\mathrm{x}$ and $\mathrm{y}$.

$$
r_{x, y}=\frac{n \sum_{i=1}^{n} x_{i} y_{i}-\sum_{i=1}^{n} x_{i} \sum_{i=1}^{n} y_{i}}{\sqrt{n \sum_{i=1}^{n} x_{i}^{2}-\left(\sum_{i=1}^{n} x_{i}\right)^{2}} \sqrt{n \sum_{i=1}^{n} y_{i}^{2}-\left(\sum_{i=1}^{n} y_{i}\right)^{2}}}
$$

Correlation coefficient takes values between -1 and 1 , where -1 means perfect negative correlation and 1 perfect positive correlation. 0 means no relation between variables. We assume, that relationship between prices should be probably described by significant positive correlation. Significance of correlation relationship can be evaluated by following test statistics:

$$
\mathrm{t}_{\mathrm{n}-2}=\frac{\mathrm{r}}{\sqrt{\frac{\left(1-\mathrm{r}^{2}\right)}{\mathrm{n}-2}}}
$$

Where $\mathrm{r}$ denotes value of correlation coefficient and $\mathrm{n}$ number of observations. In this article was significance of correlation coefficient evaluated by p-values, which is value of probability at cumulative distribution function corresponding to test statistic mentioned above. P-value smaller than 0.05 means significant correlation between variables at 0.05 level of significance.

\section{Granger Causality test}

Granger causality means causality in statistical way. This test verifies if including of $\mathrm{X}$ variable into autoregressive model of $\mathrm{Y}$ variable improves prediction of $\mathrm{Y}$. If it improves the model, then can be concluded that variable X Granger cause variable Y. In other words, if changes in variable $\mathrm{x}$ precedes 
changes in variable $\mathrm{y}$ it may suggest, that $\mathrm{x}$ cause $\mathrm{y}$. Usually it can be concluded in such case, that $\mathrm{x}$ granger cause $y$, or that change in $\mathrm{x}$ precedes change in $\mathrm{y}$. Test is based on comparison of two models. First, autoregressive model of variable considered as dependent with $\mathrm{r}$ number of lags. Number of lags was selected according to best AIC value.

$$
Y_{t}=\sum_{r=1}^{p} \alpha_{r} Y_{t-r}+u_{t}
$$

Where $\alpha_{\mathrm{r}}$ denotes parameters of model. This model is usually denoted as restricted and is compared to its unrestricted version, which includes also $r$ number of lagged values of variable $\mathrm{X}$.

$$
Y=\sum_{r=1}^{p} \alpha_{r} Y_{t-r}+\sum_{r=1}^{p} \beta_{r} X_{t-r}+u_{t}
$$

Where $\alpha$ denotes $r$ parameters of lagged $Y$ values and $\beta$ denotes $r$ parameters of lagged $X$ values. If second model will be significantly better, it can be concluded that $\mathrm{X}$ granger cause $\mathrm{Y}$. This can be verified using following test statistic:

$$
F=\frac{S S R_{R}-S S R_{U R}}{r * S S R_{U R}}(n-m)
$$

Where $\mathrm{SSR}_{\mathrm{R}}$ is residual sum of squares in restricted model, $\mathrm{SSR}_{\mathrm{UR}}$ is sum of squares of residuals in unrestricted model, $r$ is number of restrictions, $n$ number of observations and $m$ number of estimated parameters in unrestricted model. Significance of this statistics was evaluated by p-values. Granger causality was confirmed in case when p-value is smaller than level of significance. Therefore, to confirm granger causality is necessary to reject $\mathrm{H} 0$ about no causality between variables.

\section{Johansen test}

In order to analyse number of long run relationship between different markets was performed Johansen trace test. This test allows to test for number of cointegration vectors between variables. Test is based on following vector error correction model:

$$
\Delta x_{t}=\mu+A x_{t-1}+\beta_{1} \Delta x_{t-1}+\cdots+\beta_{p} \Delta x_{t-p}+w_{t}
$$

Where $\Delta x_{t}$ is the first difference of the variables in vector $\mathrm{x}, \mu$ represents the vector - valued mean of the series, $A_{i}$ are the coefficient matrices for the first lag, $\beta_{i}$ are the matrices for each differenced lag and $w_{t}$ is noise term. Johansen test checks sequentially the rank of the matrix $A$. If the rank is equal to 0 , then there is no cointegration vector. Maximum possible number of cointegration vectors is number of variables $\mathrm{m}-1$. Trace test starts with verification of $\mathrm{H} 0$ hypothesis that number of cointegration vectors $r=0$ against alternative $\mathrm{r}>0$. If $\mathrm{H} 0$ is accepted, then there is no cointegration between variables. If alternative hypothesis is accepted, test continues sequentially the same way with higher rank of $r$, until the Ho hypothesis is accepted.

\section{Vector error correction model}

If cointegration between variables was confirmed, their relationship can be expressed by vector correction mechanism. Equation of vector error correction model was already mentioned above in part about Johansen test. In case, when cointegration relationship is confirmed, matrix A can be denoted as coefficient matrix of cointegration relationship sometimes called also error correction term. This term captures the effect of the change in growth rate of $\mathrm{x}$, if one of the variables deviates from the equilibrium. Coefficient matrix A can be expressed as product $\gamma \lambda$. Cointegration matrix $\lambda$ includes information about equilibrium relationship between levels of the variables. $\gamma$ describes the speed of convergence of dependent 
variable back to its equilibrium value. Advantage of vector error correction mechanism is his ability to connect long run relationship estimated as the error correction term and short - run relationship expressed by estimated parameters of differenced variables.

\section{EMPIRICAL RESULTS AND DISCUSSION}

Table 2

Maximum and minimum values (measured in local currency), average values and variability measured by standard deviation and coefficient of variation

\begin{tabular}{|l|c|c|c|c|c|}
\hline Variable & Minimum & Maximum & Mean & Std. deviation & coefficient of variation \\
\hline NewYorkNo.16 & 18,4800 & 29,4300 & 24,3864 & 2,8480 & $11,7 \%$ \\
\hline NewYorkNo.11 & 10,4400 & 23,8900 & 16,7025 & 2,9508 & $17,7 \%$ \\
\hline LondonNo.5 & 333,6000 & 657,9000 & 463,7650 & 73,2127 & $15,8 \%$ \\
\hline ISA & 11,2700 & 23,7200 & 16,9667 & 2,8086 & $16,6 \%$ \\
\hline NewDelhi & 2357,5000 & 3945,0000 & 3236,3585 & 368,3497 & $11,4 \%$ \\
\hline Moscow,cpt & 554,8900 & 961,9800 & 729,0677 & 84,8852 & $11,6 \%$ \\
\hline SaoPauloESALQ,(taxesincl.) & $\mathbf{8 5 0 , 4 0 0 0}$ & $\mathbf{2 0 1 8 , 4 0 0 0}$ & $\mathbf{1 1 6 7 , 5 4 4 2}$ & $\mathbf{3 1 7 , 4 1 9 5}$ & $\mathbf{2 7 , 2} \%$ \\
\hline Mexico & $\mathbf{3 5 5 , 0 0 0 0}$ & $\mathbf{8 0 8 , 8 8 0 0}$ & $\mathbf{5 5 6 , 9 5 3 9}$ & $\mathbf{1 0 3 , 0 5 2 9}$ & $\mathbf{1 8 , 5 \%}$ \\
\hline
\end{tabular}

Analysed prices were characterized by descriptive statistics. Table shows their maximum and minimum values (measured in local currency), average values and variability measured by standard deviation and coefficient of variation. Last two could be used as the measures of volatility. Coefficient of variation express variability as percentage of mean and therefore can be used for comparison of volatility between different market. As can be seen in table, lowest volatility was recorded on market in New Delhi $(11,4 \%)$, then in Moscow (11,6\%) and New York No. 16 (11,7\%). Highest volatility was recorded in South American markets Sao Paulo $(27,7 \%)$ and Mexico $(18,5 \%)$.

First, relationship between prices was investigated by correlation coefficients. Strong positive correlation is assumption of similar development of prices and their interaction. Estimated correlation matrix is shown in table below. All correlation coefficients included in the table are significant at alfa 0,05. Strength of the correlation is expressed by colour tone. Positive correlations are red and negative correlations are green. Correlation does not express causation, therefore results in this table investigate similar trends in price movements, not direction of causality. New York No. 16 is strongly correlated only with Mexico. Red field in the correlation matrix suggests strong connection between prices at New York No.11, London No. 5, ISA and New Delhi. On the other side, there is only weak relationship between Moscow and other markets. There is even negative medium relationship between Moscow and South American markets. What was expected is strong relationship between South American markets, which are strongly correlated also to New York No. 16. 
Granger causality test

\begin{tabular}{|l|l|l|l|l|l|l|l|l|}
\hline & $\begin{array}{l}\text { NewYork } \\
\text { Vo.16 }\end{array}$ & $\begin{array}{l}\text { NewYork } \\
\text { No.11 }\end{array}$ & $\begin{array}{l}\text { London } \\
\text { No.5 }\end{array}$ & ISA & $\begin{array}{l}\text { New } \\
\text { Delhi }\end{array}$ & Moscow, & SaoPaulo & Mexico \\
\hline NewYorkNo.16 & $\mathbf{1}$ & $\mathbf{0 . 2 2 2 0}$ & $\mathbf{0 . 1 8 9 0}$ & $\mathbf{0 . 2 1 1 8}$ & $\mathbf{0 . 3 1 1 8}$ & $\mathbf{- 0 . 3 3 3 4}$ & $\mathbf{0 . 6 8 9 7}$ & $\mathbf{0 . 8 1 1 3}$ \\
\hline NewYorkNo.11 & $\mathbf{0 . 2 2 2 0}$ & $\mathbf{1}$ & $\mathbf{0 . 9 6 6 6}$ & $\mathbf{0 . 9 9 0 3}$ & $\mathbf{0 . 8 3 9 3}$ & $\mathbf{0 . 1 2 9 7}$ & $\mathbf{0 . 3 0 7 0}$ & $\mathbf{0 . 3 6 7 8}$ \\
\hline LondonNo.5 & $\mathbf{0 . 1 8 9 0}$ & $\mathbf{0 . 9 6 6 6}$ & $\mathbf{1}$ & $\mathbf{0 . 9 6 3 8}$ & $\mathbf{0 . 8 2 6 3}$ & $\mathbf{0 . 1 5 7 6}$ & $\mathbf{0 . 2 6 9 1}$ & $\mathbf{0 . 3 6 5 2}$ \\
\hline ISA & $\mathbf{0 . 2 1 1 8}$ & $\mathbf{0 . 9 9 0 3}$ & $\mathbf{0 . 9 6 3 8}$ & $\mathbf{1}$ & $\mathbf{0 . 8 4 2 9}$ & $\mathbf{0 . 2 1 4 9}$ & $\mathbf{0 . 2 3 7 6}$ & $\mathbf{0 . 3 1 9 6}$ \\
\hline NewDelhi & $\mathbf{0 . 3 1 1 8}$ & $\mathbf{0 . 8 3 9 3}$ & $\mathbf{0 . 8 2 6 3}$ & $\mathbf{0 . 8 4 2 9}$ & $\mathbf{1}$ & $\mathbf{- 0 . 0 7 5 2}$ & $\mathbf{0 . 4 2 8 5}$ & $\mathbf{0 . 4 6 8 6}$ \\
\hline Moscow,cpt & $\mathbf{- 0 . 3 3 3 4}$ & $\mathbf{0 . 1 2 9 7}$ & $\mathbf{0 . 1 5 7 6}$ & $\mathbf{0 . 2 1 4 9}$ & $\mathbf{- 0 . 0 7 5 2}$ & $\mathbf{1}$ & $\mathbf{- 0 . 6 3 9 1}$ & $\mathbf{- 0 . 5 6 0 6}$ \\
\hline SaoPauloESALQ, & $\mathbf{0 . 6 8 9 7}$ & $\mathbf{0 . 3 0 7 0}$ & $\mathbf{0 . 2 6 9 1}$ & $\mathbf{0 . 2 3 7 6}$ & $\mathbf{0 . 4 2 8 5}$ & $\mathbf{- 0 . 6 3 9 1}$ & $\mathbf{1}$ & $\mathbf{0 . 8 6 3 8}$ \\
\hline Mexico & $\mathbf{0 . 8 1 1 3}$ & $\mathbf{0 . 3 6 7 8}$ & $\mathbf{0 . 3 6 5 2}$ & $\mathbf{0 . 3 1 9 6}$ & $\mathbf{0 . 4 6 8 6}$ & $\mathbf{- 0 . 5 6 0 6}$ & $\mathbf{0 . 8 6 3 8}$ & $\mathbf{1}$ \\
\hline
\end{tabular}

Granger causality test was applied to investigate direction of causal relationship. This method investigates causality direction from the statistical point of view, which means, that direction of causal relationship is confirmed, if change in one variable precedes change in the other one. Or we can say, that if there is confirmed granger causality from $\mathrm{x}$ to $\mathrm{y}$, information in $\mathrm{x}$ variable significantly improve prediction of y variable. Results shown in table below are based on VAR model including four lagged values. This was selected according to AIC criterion. Columns denote explanatory variables. Their influence is tested in direction to dependent variables in rows. Table includes only p-values for Granger causality test between each pair of variables. Significant relationship from precedence point of view is confirmed in case, when $\mathrm{p}$ value is significant (smaller than 0,05) and $\mathrm{H} 0$ hypothesis suggesting no causal relationship between variables is rejected. According to results in table can be concluded, that only market which is not affected in granger causality way is London. But change in prices on London market significantly precedes change in New Delhi prices and New York 11. Change in New York16 prices does not precedes any other market and can be forecasted only by change in Mexico market (even in case of negative correlation). On the other side New York 11 granger cause ISA, New Delhi and Mexico at 0,1 significance level and is caused only by London. The most affected market according to granger causality test is New Delhi, which is caused at 0,05 significance level by London and Sao Paulo, and at 0,1 significance level by New York 11 and Mexico. Change on Moscow market is preceded only by Mexico, but significantly cause Sao Paulo, which is also preceded by New Delhi. Change in Mexico market can be significantly predicted by ISA, Sao Paulo and New York 11 prices.

Table 4

Granger causality test

\begin{tabular}{|l|l|l|l|l|l|l|l|l|}
\hline column=>row pvalue & $\begin{array}{l}\text { New York } \\
\text { No.16 }\end{array}$ & $\begin{array}{l}\text { New York } \\
\text { No.11 }\end{array}$ & $\begin{array}{l}\text { London } \\
\text { No.5 }\end{array}$ & ISA & $\begin{array}{l}\text { New } \\
\text { Delhi }\end{array}$ & Moscow & Sao Paulo & Mexico \\
\hline NewYork16 & - & 0.474 & 0.875 & 0.149 & 0.624 & 0.636 & 0.182 & $\mathbf{0 . 0 0 0} * * *$ \\
\hline NewYork11 & 0.882 & - & $\mathbf{0 . 0 5 1} *$ & 0.264 & 0.450 & 0.149 & 0.167 & 0.102 \\
\hline LondonNo5 & 0.652 & 0.535 & - & 0.561 & 0.121 & 0.464 & 0.751 & 0.468 \\
\hline ISA & 0.853 & $\mathbf{0 . 0 8 1} *$ & 0.144 & - & 0.389 & 0.102 & 0.295 & 0.185 \\
\hline NewDelhi & 0.213 & $\mathbf{0 . 0 7 9 *}$ & $\mathbf{0 . 0 0 4} * * *$ & 0.134 & - & 0.297 & $\mathbf{0 . 0 4 5} * *$ & $\mathbf{0 . 0 9 6} *$ \\
\hline Moscowcpt & 0.315 & 0.368 & 0.570 & 0.593 & 0.776 & - & 0.693 & $\mathbf{0 . 0 4 0 * *}$ \\
\hline SaoPauloESALQta & 0.117 & 0.420 & 0.588 & 0.349 & $\mathbf{0 . 0 0 8 * *}$ & $\mathbf{0 . 0 2 5 * *}$ & - & 0.167 \\
\hline Mexico & 0.233 & $\mathbf{0 . 0 9 3} *$ & 0.337 & $\mathbf{0 . 0 4 9 *}$ & 0.996 & 0.277 & $\mathbf{0 . 0 3 6 * *}$ & - \\
\hline
\end{tabular}

*** significant at $0,01 * *$ significant at $0,05 *$ significant at 0,1 
Next step in the analysis was describing long-run relationship between markets by vector error correction mechanism. Assumption of using error correction mechanism is existence of long-run relationship between markets. Prices were analysed in logarithm form and Johansen trace test was used to identify, if there exist any long-run (cointegration) relationship between prices. According to result shown in table below, there exist 3 cointegration vectors in the analysed set of prices. Trace statistics in first three lines is smaller than critical, which means rejection of hypothesis about maximum cointegration rank in its line and acceptance of hypothesis that cointegration rank is higher. Hypothesis about maximum cointegration rank was accepted in case of 3 cointegration vectors. Test was conducted using 837 observations and 4 lags. This 3 cointegration vectors could be described as New York 16, New York 11 and London prices expressed as the combination of prices on other markets. This also means, that system of relationships between analysed prices can be expressed using vector error correction mechanism.

Table 5

Vector error correction mechanism

\begin{tabular}{|l|c|c|c|c|c|}
\hline maximum rank & parms & LL & eigenvalue & trace statistic & $\mathbf{5 \%}$ critical value \\
\hline 0 & 200 & 20509.602 &. & 175.9926 & 156.00 \\
\hline 1 & 215 & 20531.859 & 0.05179 & 131.4791 & 124.24 \\
\hline 2 & 228 & 20550.188 & 0.04285 & 94.8211 & 94.15 \\
\hline $\mathbf{3}$ & $\mathbf{2 3 9}$ & $\mathbf{2 0 5 6 6 . 4 9 9}$ & $\mathbf{0 . 0 3 8 2 3}$ & $\mathbf{6 2 . 1 9 8 8} \boldsymbol{*}$ & $\mathbf{6 8 . 5 2}$ \\
\hline 4 & 248 & 20580.643 & 0.03323 & 33.9096 & 47.21 \\
\hline 5 & 255 & 20588.118 & 0.01770 & 18.9594 & 29.68 \\
\hline 6 & 260 & 20593.661 & 0.01316 & 7.41 & 15.41 \\
\hline 7 & 263 & 20597.402 & 0.00890 & 0.3923 & 3.76 \\
\hline 8 & 264 & 20597.598 & 0.00047 & & \\
\hline
\end{tabular}

Vector error correction model is link between estimation of long-run and short run relationship. Model is estimated by using differences of prices logarithm. Result of vector approach is multiple equation model, which is shown in table below. Each price is expressed as the combination of error correction term which express long run relationship and estimate speed of price transmission between markets. Model is based on VAR model with three lags, which was selected according to lowest AIC value. Equations which explains variability of London and Moscow are not significant, which suggest that these markets are not influenced by any other market, which is in accordance with previous test of Granger causality. Equation significant at alfa $=0,1$ express variability of NewYork11 and ISA. This result is close to significance threshold. According to coefficient estimates is New York 11 significantly influenced by ISA, Moscow and Sao Paulo. And ISA is similarly influenced by New York 11, Moscow and Sao Paulo. Other equations are significant at 0,01 level, despite of small $\mathrm{R}$ squared values. This suggests, that influence of other markets express approximately $5 \%$ to $10 \%$ of price variability in most markets. Highest $\mathrm{R}$ squared values were recorded in case of Sao Paulo and Mexico, which was also result of significant auto regressive scheme in these time series, where all three autoregressive coefficients were significant. New York 16 was significantly influenced by ISA and then all three lagged value of Mexico prices. New Delhi was significantly influenced by London and Mexico price, and two error correction terms were significant, which suggest long run equilibrium of New Delhi with other world markets. The most significant terms in Sao Paulo equation was its lagged term, and at 0,1 level of significance was Sao Paulo significantly influenced by New York 11 and New York 16 lagged values, and Moscow lagged by 1 . Similar results were found also in case of Mexico, which was significantly influenced 
at 0,1 level of significance by New York 16, and at 0,05 level of significance by New York 11 and ISA both lagged by 3 periods. Significant long-run relationship according to p-values of error correction terms was confirmed in New York 11 equation and New Delhi Equation.

Table 6

Vector error correction model

\begin{tabular}{|c|c|c|c|c|c|c|c|c|c|}
\hline coefficients & Depen-dent & \begin{tabular}{c|} 
difLn \\
NewYork16
\end{tabular} & \begin{tabular}{|c|} 
difLn \\
NewYork11
\end{tabular} & \begin{tabular}{|c|} 
difLn \\
LondonNo5
\end{tabular} & difLnISA & $\begin{array}{c}\text { difLnNewDelh } \\
\text { i }\end{array}$ & difLnMoscow & $\begin{array}{c}\text { difLn } \\
\text { SaoPaulo }\end{array}$ & $\begin{array}{l}\text { difLn } \\
\text { Mexico }\end{array}$ \\
\hline \multirow[t]{3}{*}{ independent } & ce1 & \begin{tabular}{l|l|}
-.0053542 \\
\end{tabular} & \begin{tabular}{|l|}
.0046423 \\
\end{tabular} & \begin{tabular}{|l|}
-.0061295 \\
\end{tabular} & .0050521 & $.0150648 * * *$ & \begin{tabular}{|l|}
.006959 \\
\end{tabular} & .0001756 & .0027463 \\
\hline & ce2 & .0096998 & $-.0889126 * *$ & -.0069258 & -.0245419 & -.0070361 & -.044659 & .0011018 & -.0565391 \\
\hline & ce3 & -.0118195 & $.0328333 *$ & -.0094859 & .0210439 & $.0336039 * * *$ & 0188521 & -.0033339 & .0235829 \\
\hline \multirow[t]{3}{*}{$\begin{array}{l}\text { difLn } \\
\text { NewYork16 }\end{array}$} & lag1 & $-.1789152 * * *$ & -.0286162 & - & -.0311488 & .0044746 & -.0344445 & .013652 & -.0010166 \\
\hline & lag2 & -.0453398 & -.0286572 & $\begin{array}{l}.0260102 \\
\end{array}$ & -.0295958 & -.0439744 & .033388 & .0179758 & -.0836136 \\
\hline & lag3 & .0149989 & .0286412 & .0039644 & .0286809 & .0138236 & -.0195038 & -.034314* & .115996* \\
\hline \multirow[t]{3}{*}{$\begin{array}{l}\text { difLn } \\
\text { NewYork11 }\end{array}$} & lag1 & -.0469584 & $.1920203 *$ & 1192919 & $.2214653 * *$ & -.0194806 & -.1183914 & -.0113554 & -.0007053 \\
\hline & lag2 & .0346489 & -.0106938 & .0833519 & .0719542 & .0107657 & -.0270279 & $.0650977 *$ & -.0738056 \\
\hline & lag3 & $-.1167647 *$ & .1232563 & .0707617 & $.1969625 * *$ & .0200691 & -.1054485 & .0299988 & $-.257274 * *$ \\
\hline \multirow{4}{*}{\begin{tabular}{|l|} 
difLn \\
LondonNo5 \\
\end{tabular}} & & & & & & & & & \\
\hline & lag1 & .012564 & .0810433 & $.1002689 *$ & .0681431 & .0401216 & .0509668 & . 0185623 & .1174428 \\
\hline & lag2 & .0417346 & -.0257371 & -.0682442 & .0719542 & $-.082973 * *$ & .0212367 & .0036815 & -.0950129 \\
\hline & lag3 & -.0018612 & -.055175 & -.0217741 & -.0360673 & -.0072979 & .0127584 & -.0185866 & -.0281292 \\
\hline \multirow[t]{3}{*}{ difLnISA } & lag1 & .0930759 & $-.2721664 * *$ & $-.1926308 *$ & $-.2543377 * *$ & -.0241632 & .0426128 & .0177179 & -.0504601 \\
\hline & lag2 & -.0462514 & .017369 & -.0520817 & -.0726644 & .0330363 & .0483581 & -.0567299 & .1638922 \\
\hline & lag3 & $.1985926 * *$ & -.0636359 & -.0143478 & -.164423 & -.0211186 & 1046879 & .0152236 & $.3661424 * *$ \\
\hline \multicolumn{10}{|l|}{ difLn } \\
\hline \multirow[t]{3}{*}{ NewDelhi } & lag1 & . 0395232 & .011445 & . 0235517 & .0024879 & $-.109439 * * *$ & -.0123984 & . 0278175 & . \\
\hline & lag2 & .0395232 & .0062199 & .0656755 & .0036358 & $.1036581 * * *$ & .0340819 & -.0014004 & .0203428 \\
\hline & lag3 & .0455353 & $\begin{array}{l}.088419 \\
\end{array}$ & -.0695222 & $\begin{array}{l}.0597504 \\
\end{array}$ & .0286617 & .0544774 & .0213446 & .0178109 \\
\hline \multirow[t]{3}{*}{$\begin{array}{l}\text { difLn } \\
\text { Moscowcpt }\end{array}$} & lag1 & -.0078286 & . 0521042 & . 0192282 & . 0442185 & -.0139225 & . 0311013 & $.0227333 *$ & -.043015 \\
\hline & lag2 & .0122636 & $-.0804045 * *$ & -.0424441 & $-.0665265 * *$ & -.0069919 & .0156155 & .0032355 & -.0192828 \\
\hline & $\operatorname{lag} 3$ & .0127588 & -.0602519 & -.0444276 & $-.0624688 *$ & -.0142384 & .0000481 & .0074842 & .0647327 \\
\hline \multirow[t]{3}{*}{$\begin{array}{l}\text { difLn } \\
\text { SaoPaulo }\end{array}$} & lag1 & -.003123 & . 0866669 & -.0161708 & .0246011 & . 0051674 & - 0427885 & $.2309884 * * *$ & (0385289 \\
\hline & lag2 & .0341249 & $.2143909 * *$ & .0988419 & $.187362 * *$ & .0204002 & .0108358 & $\begin{array}{l}.063884 * \\
\end{array}$ & .0431178 \\
\hline & lag3 & .0021873 & -.032665 & -.0622702 & -.1160659 & -.0027908 & .0781938 & $.1975036 * * *$ & .1111658 \\
\hline \multirow[t]{3}{*}{ difLnMexico } & lag1 & $.0498951 * *$ & -.0056107 & -.0026339 & -.0020271 & $.0354252^{* *}$ & -.0025205 & .0079207 & $-.6730723 * * *$ \\
\hline & lag2 & $.0495228 * *$ & $.0696481 *$ & .0262484 & .0531967 & .0211012 & -.0111752 & .0110429 & $-.3831296 * * *$ \\
\hline & lag3 & $.0935129 * * *$ & .0164193 & .0158249 & .0200262 & .0258243 & -.0003436 & .0035982 & $-.1443475 * * *$ \\
\hline \multirow[t]{3}{*}{ const } & & -.0000908 & -.0000614 & -.0001788 & -.0002299 & .0000208 & -.0002295 & .000445 & .00039 \\
\hline & $\mathrm{R}^{\wedge} 2$ & 0,08 & 0,05 & 0,03 & 0,05 & 0,1 & 0,02 & 0,24 & 0,35 \\
\hline & $\begin{array}{l}\mathrm{P} \text {-value } \\
\text { nat }\end{array}$ & 0 & 0,07 & 0,59 & 0,052 & 0,00007 & 0,78 & 0 & 0 \\
\hline
\end{tabular}

Figure below shows distribution of prices at selected the most important markets, and their interaction described by scatter plots. Both New York and ISA markets are close to normal distribution. Other markets, especially Mexico, Sao Paulo and New Delhi shows different pattern. This influences also strange correlation pattern in relation of these markets with others. This is in contrast with standard correlation patterns of New York 16 and 11, London and Isa markets. 


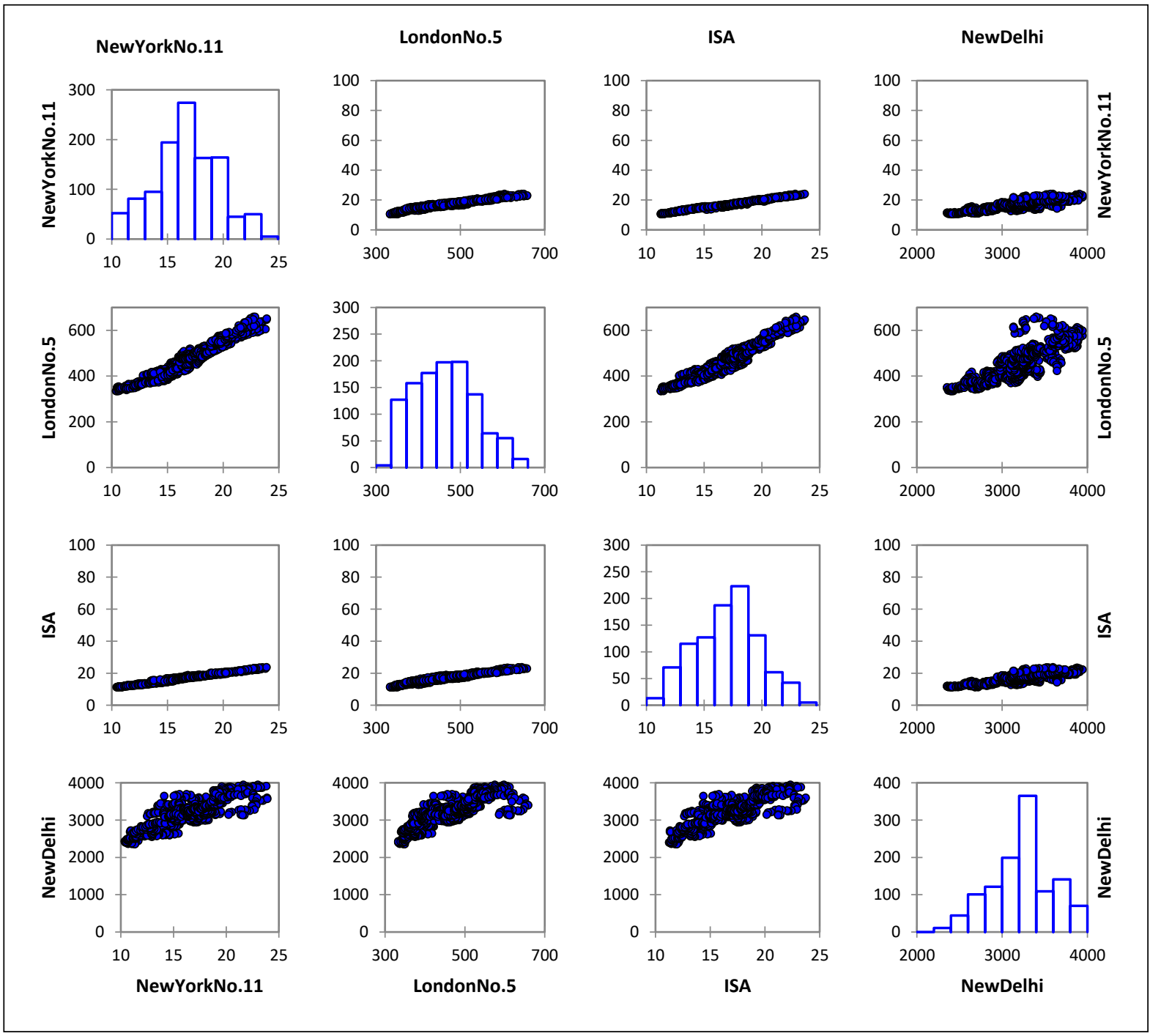

Figure 7. Correlation matrix of the most significant relationships in analysed set of variables

Figure above shows scatter plot matrix of markets with highest correlations: New York 11, London No. 5, ISA and New Delhi. Strongest correlation is between ISA and New York 11, but ISA is also strongly correlated with London No. 5. Relationship with similar strength measured by correlation coefficient is also between New York 11 and London. No 5. All charts are close to straight line. Less intensive but also very strong correlation was recorded between New Delhi and all these markets, but there is obvious higher spread of observations from straight line. Diagonal figures show distribution of each price. All of them are close to normal, in case of London and New Delhi little bit skewed.

Figures below shows selected impulse-response functions. First shows response of New York 16, to impulse in ISA, Mexico and New York 11. Impulse in New York 11 cause only slightly change and get stabilized after three periods with slightly decrease. Impulse in ISA cause significant response after three periods with delayed increase. On impulse in Mexico market reacts New York 16 by continuous increase. Peak of the response is in third period. 

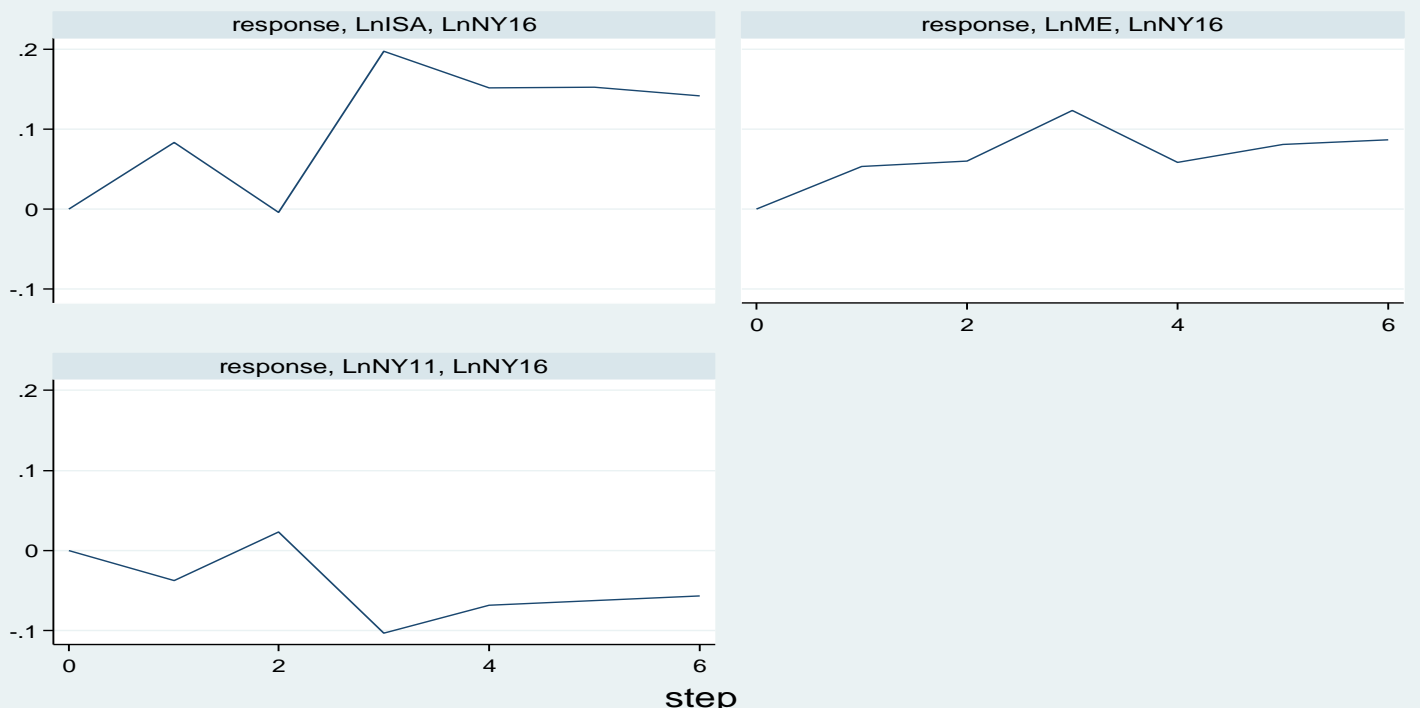

Graphs by irfname, impulse variable, and response variable

Figure 8. Selected impulse- response functions (response of New York 16, to impulse in ISA, Mexico and New York 11)

Similarly is shown also response of New York 11 to ISA, New York 16 and Sao Paulo impulse. Impulse from New York 16 does not cause any significant response on New York 11 market. Impulse caused by ISA cause slight decrease in first period, but price recover after five periods to its original value. Impulse from Sao Paulo cause significant increase in New York 11 with fast increase in first two periods and then continue in slightly increasing trend.
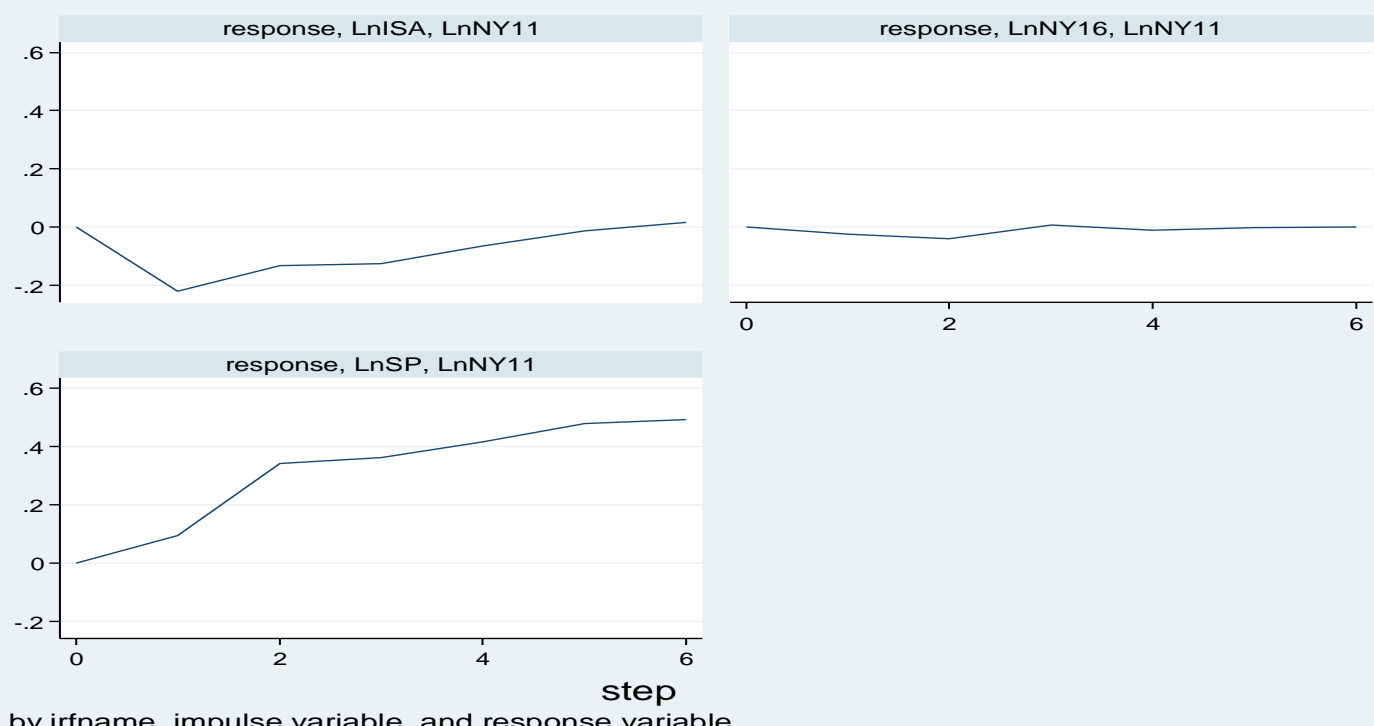

Graphs by irfname, impulse variable, and response variable

Figure 9. Selected impulse- response functions (response of New York 11 to ISA, New York 16 and Sao Paulo impulse)

On the figure below is shown response of London to impulse from ISA, New York 16 and New York 11. Impulse coming from New York 16 does not cause any significant response at London market. On the 
other side, impulse from New York 11 cause significant increase in 3 periods. Imulse from ISA Market cause significant decrease in London market, which is stabilized after 2 periods.

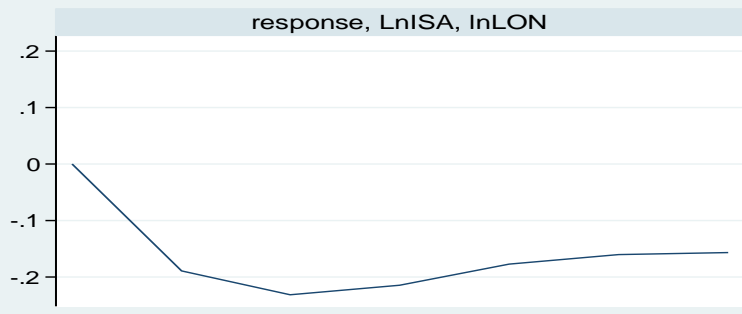

response, LnNY16, InLON

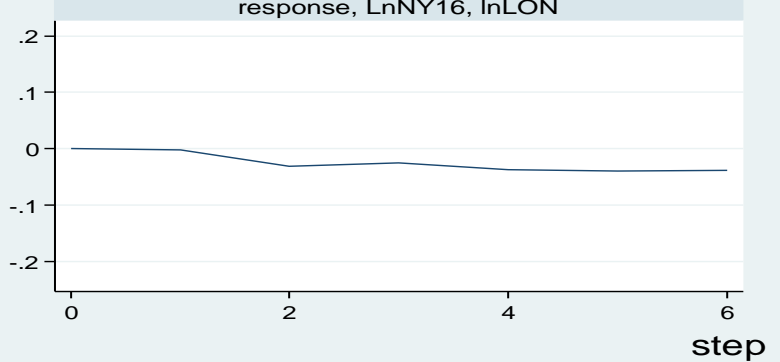

Graphs by irfname, impulse variable, and response variable

\section{York 16 and New York 11)}

Individual above-mentioned figures also proved the reaction of ISA to impulse from New York 11 and New York 16 and London. In the case of impulse coming from New York 16 is not recorded any significant response. Impulse from London market cause only slight increase. Impulse from New York 11 cause significant increase in ISA market with correction in later periods.

\section{CONCLUSION}

During the last decade, the world sugar market passed through the significant process of territorial and processing capacities structure transformation. As sugar is considered to be the key commodity for stability of food market and also for individual countries' self-sufficiency, the global sugar market has been suffering because of massive protectionisms and governments' interventions. These interventions usually result in a limitation or distortion of price transmission among markets in contrast to a free market mechanism. All these circumstances aroused our interest to investigate the extent of interconnection among sugar markets in different parts of the world (represented by eight major sugar price makers - sugar exchange stocks/markets and International Sugar alliance) and predetermined the goal of this study to analyse the very fact of the existence of a long-term equilibrium among them. The very fact of the existence of such a long-term equilibrium bears important implications as for potential investors, so as for sellers. Eventually, the quantification of the degree to which the analysed sugar markets are connected have materially augmented the understanding of the latest sugar price developmental trends. The conducted analysis revealed the existence of mutual interaction among selected sugar markets/commodity stock exchanges in selected regions and confirmed the long-term equilibrium among them. However, the local sugar price is rather different region by region, country by country. On the other hand, selected regional commodity stocks exchanges' analyses proved the existence of relations among the key commodity stocks. There was confirmed strong relation between ISA, New York 11 and London No. 5. Granger Causality test confirmed 
strong position of London No.5 and New York 11, which influence other markets. There was confirmed also causality in direction from New Delhi to Sao Paulo and from Sao Paulo to Mexico. Results of the VECM confirmed Granger causality and strong position of New York 11 and emphasized also role of ISA: In comparison of results obtained by correlation, causality and error correction mechanism, was confirmed important role of New York 11 in all these analyses. Thus, the hypothesis of mutual sugar markets interdependence was confirmed, suggesting that investigation of cointegration is useful and relevant for all interested parties. At the same time, the results of the present study opened space and mapped out clear objectives and measurable targets for potential research - to reveal what markets can be referred to as leading ones in a sense that they primarily act as a source of price turbulence. In other words, the goal of the potential study could be to identify markets-drivers of price changes, markets-transmitters and marketsrecipients.

\section{ACKNOWLEDGEMENT}

This paper is supported by a grant project of National Agency for Agricultural Research (NAZV). The project title is "Duality in Czech Agriculture: Advantage or Disadvantage for New Generation Agriculture?”, (QK1920398).

\section{REFERENCES}

Babuněk, O. (2016). Comparison of Impact of Selected Aspects on Supply, Demand and Price of Sugar in Developing and Developed Countries, in the World, in OECD and EU Countries. Listy cukrovarnické a repařské, 132(5-6), 19.

Barassi M.R. \& Ghoshray A. (2007). Structural Change and Long-run Relationship between US and EU Wheat Export Prices. Journal of Agricultural Economics, 58, 76-90.

Bilyk, O., Khalikova, E., Shevchenko, A., Kochubei-Lytvynenko, O., Bondarenko, Y., \& Fain, A. (2020). Effect of the complex improver on consumer properties of bakery products. Ukrainian Food Journal, 9(1). 148-158

Crago, L.C., Khanna, M., Barton, J., Giuliani, E. \& Amaral, W. (2010). Competitiveness of Brazilian Sugarcane Ethanol Compared to US Corn Ethanol. Poster prepared for presentation at the Agricultural and Applied Economics Association 2010 AAEA, CAES, and WAEA Joint Annual Meeting, Denver, Colorado, July 25-27, 2010. Colorado, USA.

Čermák, M., Malec, K. and Maitah, M. (2017) "Price Volatility Modelling - Wheat: GARCH Model Application", AGRIS on-line Papers in Economics and Informatics, 9(4), 15-24. DOI: 10.7160/aol.2017.090402.

Dimpfl, T. \& Peter, F. J.(2018). Analyzing volatility transmission using group transfer entropy. Energy Economics, 75, 368-376. DOI: $10.1016 /$ j.eneco.2018.08.008

Drabik, D., De Gorter, H., Just, D. R. \& Timilsina, G. R. (2014). The economics of Brazil's ethanol-sugar markets, mandates, and tax exemptions. American Journal of Agricultural Economics, 97(5), 1433-1450. DOI: 10.1016/j.physa.2018.08.080

Elobeid, A. \& Beghin, J. (2006). Multilateral trade and agricultural policy reforms in sugar markets. Journal of Agricultural Economics, 57(1), 23-47. DOI: 10.1111/j.1477-9552.2006.00030.x

F.O.Licht, (2020). (available et: https://www.agra-net.com/agra/international-sugar-and-sweetener-report/); (on-line: $10 / 05 / 2020)$

Frate, C. A. \& Brannstrom, C. (2015). Will Brazil's ethanol ambitions undermine its agrarian reform goals? A study of social perspectives using Q-method. Journal of Rural Studies, 38, 89-98. DOI: 10.1016/j.jrurstud.2014.10.007

Fuller, K. \& Kennedy, P.L. (2019). A determination of factors influencing sugar trade. International Journal of Food and Agricultural Economics 7(1), 19-29. DOI: 10.22004/ag.econ.283880

Garside, B. et al. (2004). Who gains from sugar quotas? , DESTIN DV406 Research Project: London School of Economics and Overseas Development Institute, 2004.

Grethe, H., Nolte, S. \& Banse, M., (2008). Modelling the Efects of EU Sugar Market Liberalization on Area Allocation, Production and Trade. Contribution to conference, 107th EAAE Seminar on Modelling Agricultural and Rural Development Policies, Sevilla, January 31- February 01, 2008. Sevilla, Spain. 
Haley, S. \& Polet, Z., (2011) Post-Reform European Union Sugar - Prospects for the Future, Gain Report No. E60078. Haley, S. (2013). World Raw Sugar Prices The Influence of Brazilian Costs of Production and World Surplus/Deficit Measures, A Report from the Economic Research Service, 22, SSS-M-297-01.

Hndi B. M., Maitah, M. and Mustofa, J. (2016) "Trade Impacts of Selected Free Trade Agreements on Agriculture: The Case of Selected North African Countries", AGRIS on-line Papers in Economics and Informatics, 8(3), 39 - 50. DOI: $10.7160 /$ aol.2016.080304.

Jacomini, R.L. \& Burnquist, H.L. (2018). Asymmetric price transmission in the Brazilian refined sugar market. Italian Review of Agricultural Economics, 73(1), 5-25. DOI: https://doi.org/10.13128/REA-23576

Koo, Won W. \& Taylor Richard D. (2012). 2012 Outlook of the U.S. and World Sugar Markets, 2011-2021, Agribusiness \& Applied Economics Report N. 692, Center for Agricultural Policy and Trade Studies. North Dakota State University, Fargo.

Kovářová, K., Nádeník, M. \& Pícha, K. (2017). The Czech Republic Sugar Market Development in the Context of the Phasing out of Sugar Quota. Deturope, , 9(2), 110-117.

Kramer, E. (2016). U.S Sugar Beet Price Analysis. Research Papers Southern Illinois University Carbondale, 39.

Krejčí, T., Dostál, I., Havlíček, M., \& Martinát, S. (2016). Exploring the hidden potential of sugar beet industry brownfields (case study of the Czech Republic). Transportation Research Part D, 46, 284-297. DOI: 10.1016/j.trd.2016.04.006

Lima, C. R. A., De Melo, G. R., Stosic, B. \& Stosic, T. (2019). Cross-correlations between Brazilian biofuel and food market: Ethanol versus sugar. Physica A: Statistical Mechanics and its Applications, 513, 687-693. DOI: 10.1016/j.physa.2018.08.080

McConnell, M, Dohlman, E. \& Haley, S. (2010). World Sugar Price Volatility Intensified by Market and Policy Factors. Amber Wawes Feature, Economic research service USDA, 2010, 8(3), 28-35.

Moyo, S., \& Spreen, T. H. (2011). An Update on the Consequences of EU Sugar Reform. International Journal on Food System Dynamics, 2(1), 2011, 67-76. DOI: 10.18461/ijfsd.v2i1.215

Nagyová, L., Horská, E., \& Kádeková, Z. (2011). Food quality policy and labelling. Delhi Business Review, 12(1), 85100.

Pereda, P., Christofoletti, M.A., Wen Ng, S, Claro, R.M., Duran, A.C. \& Monteiro, C.A. (2019). Effects of a $20 \%$ price increase of sugar-sweetened beverages on consumption and welfare in Brazil, Working Papers, Department of Economics 2019_33, University of São Paulo (FEA-USP).

Pop, L., Rovinaru, M. \& Rovinaru, F. (2013). The challenges of sugar market: an assessment from the price volatility perspective and its implications for Romania. Procedia Economics and Finance, 5, 605-614. DOI: 10.1016/S22125671(13)00071-3

Récky, R. (2014) The evaluation of chosen economics and marketing indicators of sugar cultivation in Slovakia In: Improving performance of agriculture and the economy: challenges for management and policy. International Scientific days 2014, SUA Nitra, 110.

Rezbová, H., Belová A. \& Škubna, O. (2013). Sugar beet production in the European Union and their future trends, Agris online Papers in Economics and Informatics, Prague, 5(4), 165-178. DOI: 10.22004/ag.econ.162299

Rezbová, H. Maitah, M., Sergienko, O. I. (2015) "EU Quota Sugar Market Concentration - the Main Drivers of EU Sugar Market", AGRIS on-line Papers in Economics and Informatics, 7 (4), 131- 142.

Rodrigues L. \& Moraes M. (2007). Market structure of the refining industry in the Central and South Brasil region. Journal of Rural Economy and Sociology, 45(1): 93-118.

Serra, T., Zilberman, D. \& Gil, J. (2010). Price volatility in ethanol markets. European review of agricultural economics, 38(2), 259-280. DOI: 10.1093/erae/jbq046

Severová, L., Kopecká, L., Svoboda, R. et al. (2011). Oligopoly competition in the market with food product, Agricultural Economics - Zemédèlská Ekonomika, 57(12), 580 - 588. DOI: 10.17221/107/2010-AGRICECON

Surca, D.E. (2017). Sugar market in the European Union and Romania. Study on price developments. Agrarian Economy and Rural Development - Realities and Perspectives for Romania. 8, 217-223.

Svatoš, M., Maitah, M. \& Belova, A. (2012). World Sugar Market - Basic Development Trends and Tendencies, Agris on-line Papers in Economics and Informatics, Prague, 4(2), 73-88. DOI: 10.22004/ag.econ.152692 
Taylor Richard D. (2017). 2017 Outlook of the U.S. and World Sugar Markets, 2016-2026, Agribusiness \& Applied Economics Report N. 767, Center for Agricultural Policy and Trade Studies. North Dakota State University, Fargo.

Zamsa, S. (2015). "World Sugar Market Outlook: 2014-2015," Revista de Economie Mondiala / The Journal of Global Economics, Institute for World Economy, Romanian Academy, vol. 7(2).

Zimmermann, B. \& Zeddies, J. (2002). International Competitiveness of Sugar Production, the 13th International Farm Management Congress, Wageningen, The Netherlands. 